\title{
Thermal Annealing Effect on Poly(3-hexylthiophene): Fullerene:Copper-Phthalocyanine Ternary Photoactive Layer
}

\author{
H. Derouiche and A. B. Mohamed \\ Laboratoire de Photovoltaïques, Centre de Recherches et des Technologies de l'Energie, BP 95, 2050 Hammam-Lif, Tunisia \\ Correspondence should be addressed to H. Derouiche; hderouiche@yahoo.fr
}

Received 10 April 2013; Accepted 8 May 2013

Academic Editors: A. Hermann, V. Kazukauskas, A. Ovchinnikov, and A. Savchuk

Copyright ( $) 2013$ H. Derouiche and A. B. Mohamed. This is an open access article distributed under the Creative Commons Attribution License, which permits unrestricted use, distribution, and reproduction in any medium, provided the original work is properly cited.

\begin{abstract}
We have fabricated poly(3-hexylthiophene) (P3HT)/copper phthalocyanine (CuPc)/fullerene (C60) ternary blend films. This photoactive layer is sandwiched between an indium tin oxide (ITO)/poly(3,4-ethylenedioxythiophene):poly(styrene sulfonate) (PEDOT/PSS) photoanode and a bathocuproine (BCP)/aluminium photocathode. The thin films have been characterized by atomic force microscope (AFM) and ultraviolet/visible spectroscopy in order to study the influence of P3HT doping on the morphological and optical properties of the photoactive layer. We have also compared the $I-V$ characteristics of three different organic solar cells: ITO/PEDOT:PSS/CuPc $0.5: \mathrm{C} 60_{0.5} / \mathrm{BCP} / \mathrm{Al}$ and ITO/PEDOT:PSS/P3HT $0.3: \mathrm{CuPc}_{0.3}: \mathrm{C} 60_{0.4} / \mathrm{BCP} / \mathrm{Al}$ with and without annealing. Both structures show good photovoltaic behaviour. Indeed, the incorporation of P3HT into CuPc:C60 thin film improves all the photovoltaic characteristics. We have also seen that thermal annealing significantly improves the optical absorption ability and stabilizes the organic solar cells making it more robust to chemical degradation.
\end{abstract}

\section{Introduction}

Thin films composed of copper phthalocyanine $\mathrm{CuPc}$ and fullerene $\mathrm{C} 60, \mathrm{p}-\mathrm{n}$ small molecules, have in recent years received increasing attention, due to new optoelectronic applications [1-4]. CuPc:C60 composite film was commonly used to obtain a high conversion efficiency of solar energy into electrical energy [5-8]. However, there is incomplete knowledge about physical and chemical mechanisms of organic thin films stability [9-11].

Addition of polymer is proposed as a way to stabilize the CuPc:C60 thin films, making it more robust to chemical degradation. Regioregular poly(3-hexylthiophene) (P3HT) polymers are widely used in organic devices [12-15]. P3HT has a good chemical stability and good solubility in various solvents, so the addition of P3HT to the CuPc:C60 thin films improves the $\mathrm{p}-\mathrm{n}$ bulk heterojunction.

Moreover, thermal annealing is an effective method that improves the morphology, compactness, and crystallinity of the organic thin films [16-19]. One of the most important effects of thermal annealing is the reorientation of the $\mathrm{CuPc}$ planar and C60 near-spherical shape small molecules in a high density P3HT matrix.
The aim of the present work is to study the influence of P3HT doping and thermal annealing on the structural, optical, and stability of the fullerene-based solar cells.

\section{Experimental Details}

All the organic layers have been deposited in a sandwich geometry between the two electrodes: indium tin oxide (ITO) as photoanode and aluminum as photocathode (Figure 1).

The ITO-coated glass substrates (Aldrich, surface resistivity $8-12 \Omega /$ sq) were treated with an $80^{\circ} \mathrm{C} \mathrm{H}_{2} \mathrm{O}-\mathrm{H}_{2} \mathrm{O}_{2}$ (30\%)$\mathrm{NH}_{4} \mathrm{OH}(25 \%)$ solution $(5: 1: 1 \mathrm{vol}$. parts) for $20 \mathrm{~min}$ and then cleaned in sequence with acetone $(15 \mathrm{~min})$ and isopropanol (15 min) and deionized water (15 min) using an ultrasonic bath.

PEDOT:PSS, $0.54 \%$ in $\mathrm{H}_{2} \mathrm{O}$, high-conductivity grade with 1-5\% Propan-2-ol, and 5-10\% diethylene glycol were purchased from Aldrich. It is the most hole transparent conductor used as buffer layer, having a good charge transport properties (resistance of $200 \Omega / \mathrm{sq}$ ). In addition, single-walled carbon nanotubes (SWNTs) were dispersed in a PEDOT:PSS 


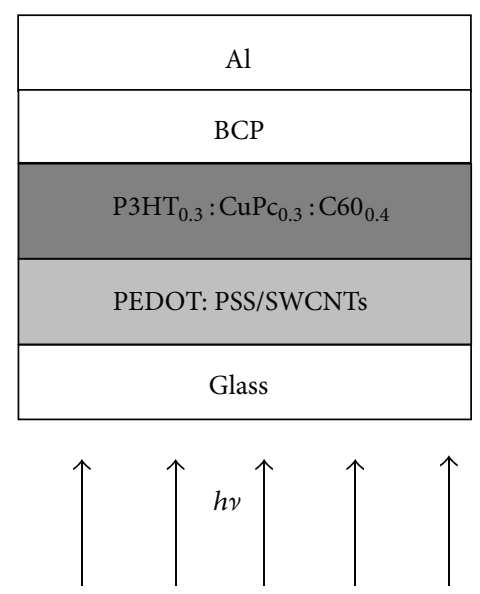

FIGURE 1: Structure of ITO/PEDOT:PSS/C60:CuPc:P3HT/BCP/Al solar cell.

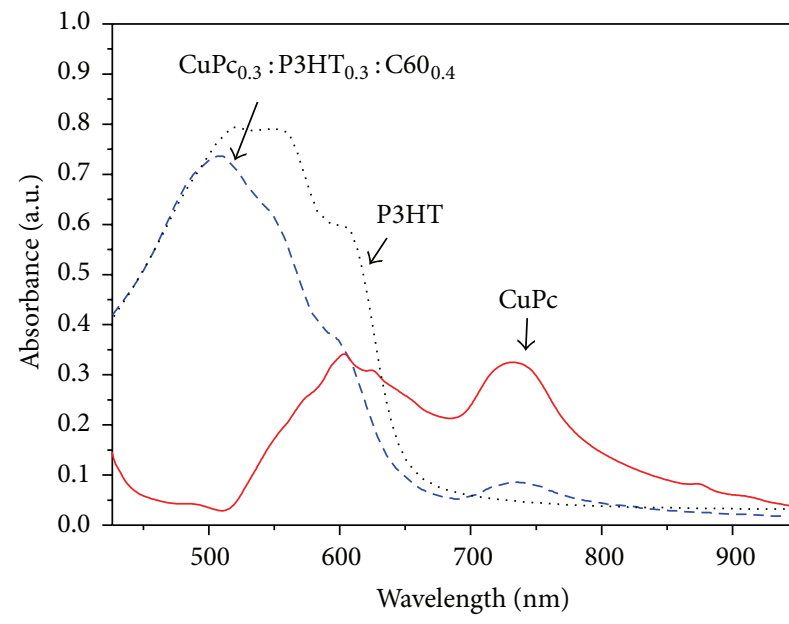

(a)

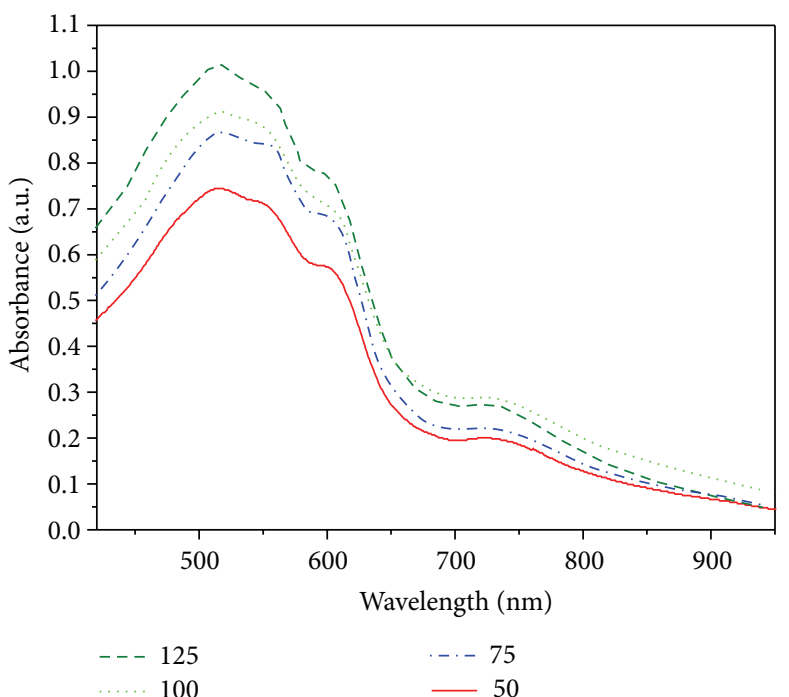

(b)

Figure 2: The absorbance spectra of (a) CuPc (solid line), P3HT (dotted line), and $\mathrm{P}_{3} \mathrm{HT}_{0.3}: \mathrm{CuPc}_{0.3}: \mathrm{C} 60_{0.4}$ before annealing (dashed line) and (b) $\mathrm{P}_{3} \mathrm{HT}_{0.3}: \mathrm{CuPc}_{0.3}: \mathrm{C} 0_{0.4}$ after annealing at different temperatures.

solution with a weight ratio of $0.5 \mathrm{wt} \%$, and the obtained solutions were spin coated onto ITO.

As for $\mathrm{CuPc}, \mathrm{C60}$, and P3HT, they were purchased from Aldrich and used without further purification. In this work, polymer solutions were prepared by dissolving $\mathrm{P} 3 \mathrm{HT} / \mathrm{CuPc} / \mathrm{C} 60$ with weight ratios of $30: 30: 40$ in dichlorobenzene. The thickness was checked by cross- section visualization using SEM.

In addition, bathocuproine (BCP) and aluminum upper contacts were deposited onto the organic layers by vacuum evaporation at a pressure of $10^{-4} \mathrm{~Pa}$. A mask was used to determine a well-defined shape for the aluminum electrode.

Finally, to increase the stability of the organic cell, polyvinylidene difluoride (PVDF) film was put on top of the organic solar cell and annealed for $5 \mathrm{~min}$ at $70^{\circ} \mathrm{C}$. This encapsulation method limits diffusion of oxygen and water into the active layer.

\section{Results and Discussion}

Figure 2(a) shows the absorption spectra of a $\mathrm{CuPc}, \mathrm{P} 3 \mathrm{HT}$, and $\mathrm{P}_{3} \mathrm{HT}_{0.3}: \mathrm{CuPc}_{0.3}: \mathrm{C} 0_{0.4}$ films. $\mathrm{CuPc}$ has a strong absorption in the visible region, with the Q-band absorption peaks at around 620 and $740 \mathrm{~nm}$ related to the $\pi-\pi^{*}$ transition [20]. For pure $\mathrm{P} 3 \mathrm{HT}$ film, the absorption spectra showed two peaks at $493 \mathrm{~nm}$ and $517 \mathrm{~nm}$ and one shoulder at $572 \mathrm{~nm}$. These three bands can be attributed to the $\pi-\pi^{*}$ transition [21]. As for $\mathrm{P}_{3} \mathrm{HT}_{0.3}: \mathrm{CuPc}_{0.3}: \mathrm{C}_{00}$ ternary blend bulk heterojunction, broadening and splitting of the absorption spectrum are observed. The presence of the strong vibronic feature near $600 \mathrm{~nm}$ is attributed to P3HT interchain interaction [22].

Figure 2(b) shows the effect of thermal annealing on the $\mathrm{UV}-\mathrm{Vis}$ absorption spectra for the thin films of $\mathrm{P}_{3} \mathrm{HT}_{0.3}$ : $\mathrm{CuPc}_{0.3}: \mathrm{C} 60_{0.4}$. The annealing time here is $15 \mathrm{~min}$ for all the films. Optical intensities of the peaks at both $550 \mathrm{~nm}$ 


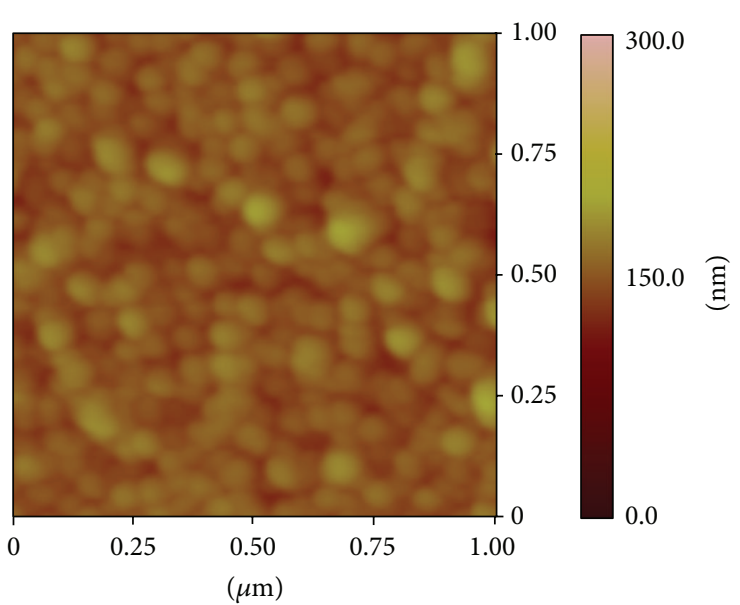

(a)

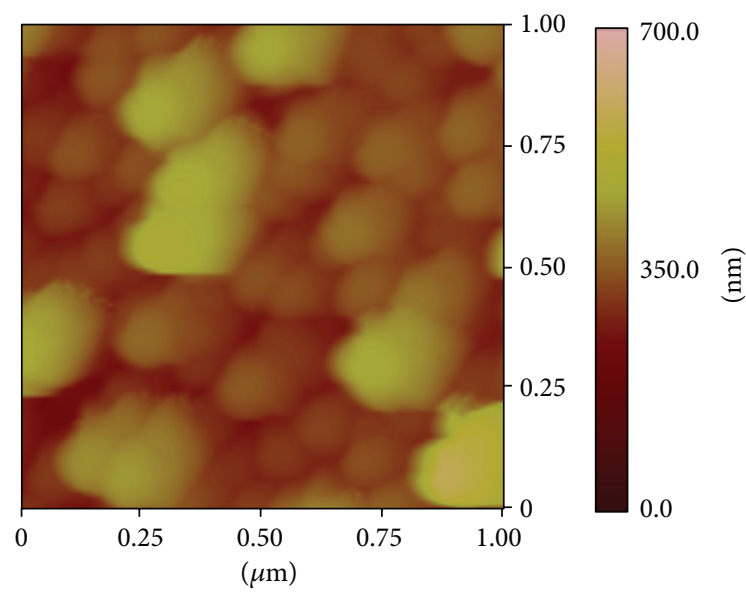

(b)

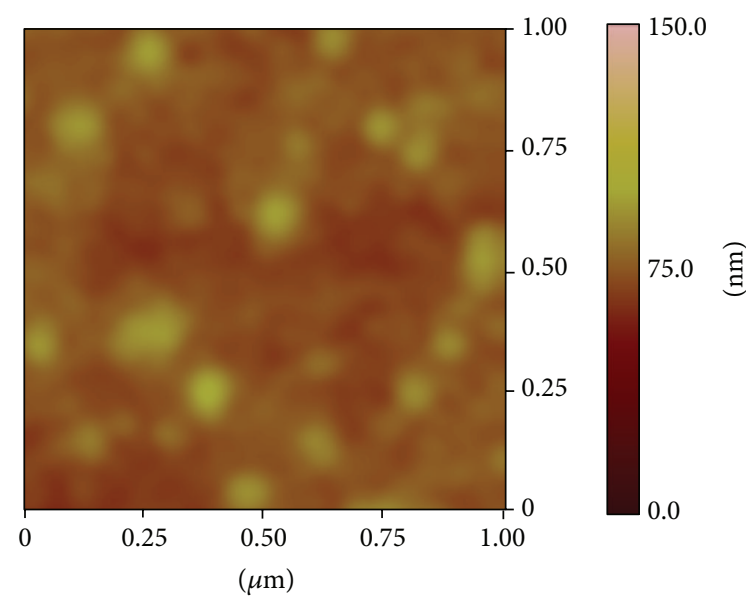

(c)

Figure 3: AFM image of (a) C60, (b) CuPc:C60, and (c) $\mathrm{P}_{3} \mathrm{HT}_{0.3}: \mathrm{CuPc}_{0.3}: \mathrm{C} 60_{0.4}$ thin films.

and $600 \mathrm{~nm}$ correspondent to P3HT were improved as the annealing temperature is increased; this indicates an enhanced ordering of the organic materials in the thin film [23]. However, the optical intensity of the peaks at $740 \mathrm{~nm}$ correspondent to $\mathrm{CuPc}$ decreased as the annealing temperatures were higher than $100^{\circ} \mathrm{C}$. The degradation is possibly due to the change in orientation of the $\mathrm{CuPc}$ planar and C60 nearspherical shape small molecules in the $\mathrm{P} 3 \mathrm{HT}_{0.3}: \mathrm{CuPc}_{0.3}: \mathrm{C} 60_{0.4}$ thin films.

AFM (Figure 3) observations allow visualizing of the surface structure of $\mathrm{C} 60, \mathrm{CuPc}_{0.5}: \mathrm{C}_{00}$, and $\mathrm{P}_{0.5} \mathrm{HT}_{0.3}: \mathrm{CuPc}_{0.3}$ : $\mathrm{C} 60_{0.4}$ thin films after thermal annealing for $15 \mathrm{~min}$ at $100^{\circ} \mathrm{C}$. Fullerene C60 thin films (Figure 3(a)) form crystalline structures. After the addition of $\mathrm{CuPc}$ (Figure $3(\mathrm{~b})$ ), $\mathrm{CuPc}_{0.5}: \mathrm{C} 0_{0.5}$ clearly show the presence of dense packing film with a smooth surface and demonstrate highly ordered surface composed of C60 agglomeration and $\mathrm{CuPc}$ molecular planes. AFM images of $\mathrm{C} 60, \mathrm{CuPc}_{0.5}: \mathrm{C} 60_{0.5}$ (Figure 3(c)) show that the formation of an amorphous thin film composed of C60:CuPc agglomerates into an amorphous matrix of $\mathrm{P} 3 \mathrm{HT}$.

Typical $I-V$ measurements under AM 1.5 illuminations of the devices are plotted in Figure 4. ITO/PEDOT:PSS/
$\mathrm{CuPc}_{0.5}: \mathrm{C} 60_{0.5} / \mathrm{BCP} / \mathrm{Al}$, we have a $V_{\mathrm{OC}}$ of $0.52 \mathrm{~V}$, an $I_{\mathrm{SC}}$ of $4.93 \mathrm{~mA} / \mathrm{cm}^{2}$, and a fill factor of 0.4 giving energy conversion efficiency of $1.02 \%$. For the ITO/PEDOT:PSS/ $\mathrm{P}_{3} \mathrm{HT}_{0.3}: \mathrm{CuPc}_{0.3}: \mathrm{C} 60_{0.4} / \mathrm{BCP} / \mathrm{Al}$ device develops an open circuit voltage $V_{\mathrm{OC}}$ of $0.55 \mathrm{~V}$, an $I_{\mathrm{SC}}$ of $5.7 \mathrm{~mA} / \mathrm{cm}^{2}$, and a fill factor of 0.46 giving energy conversion efficiency of $1.44 \%$.

All structures show significant photovoltaic behaviour. The most remarkable feature is an increase in the short circuit current at P3HT doping. In fact, under illumination, a fraction of incorporated $\mathrm{P} 3 \mathrm{HT}$ polymers improve photon absorption of the CuPc system leading to a higher number of free holes in the valence band, which establishes a p-type doping inside the materials. Furthermore, P3HT polymers can also act as exciton dissociation sites and therefore generate free charge carriers in the presence of excitons. On the other hand, with $\mathrm{P} 3 \mathrm{HT}$, both the open-circuit voltage and the fill factor increase, respectively, to a value around $0.55 \mathrm{~V}$ and 0.46 compared to $0.52 \mathrm{~V}$ and 0.4 . Therefore, we can note that the open-circuit voltage and the fill factor depend on the nature of the photoactive polymers.

After thermal annealing of the photoactive layer for $15 \mathrm{~min}$ at $100^{\circ} \mathrm{C}$, ITO/PEDOT:PSS/P3HT ${ }_{0.3}: \mathrm{CuPc}_{0.3}:{\mathrm{C} 60_{0.4} /}$ 


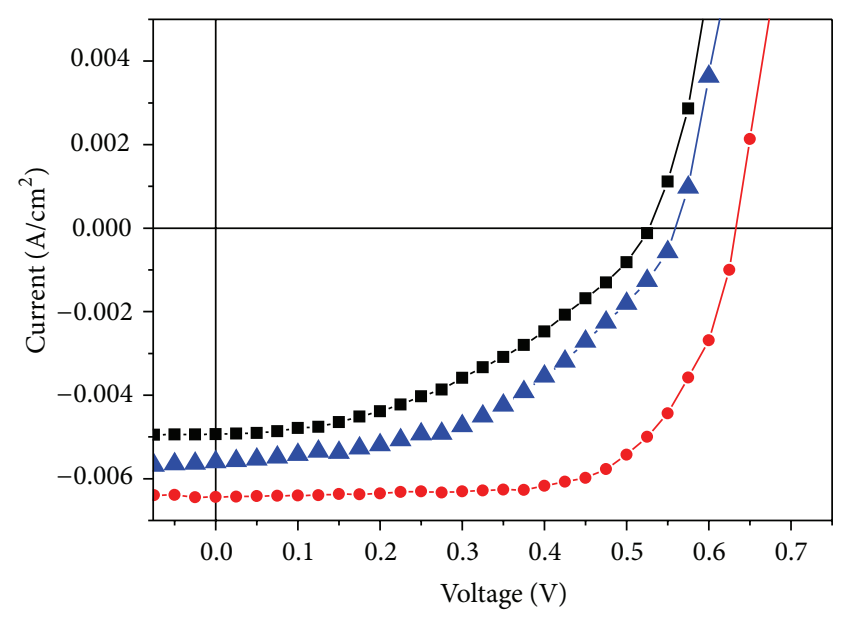

FIgURE 4: $I(V)$ characteristics of (i) ITO/PEDOT:PSS/P3HT ${ }_{0.3}$ : $\mathrm{CuPc}_{0.3}: \mathrm{C}_{00} / \mathrm{BCP} / \mathrm{Al}$ heat-treated (•), (ii) ITO/PEDOT:PSS/ $\mathrm{P} 3 H T_{0.3}: \mathrm{CuPc}_{0.3}: \mathrm{C} 60_{0.4} / \mathrm{BCP} / \mathrm{Al}(\boldsymbol{\Delta})$, and (iii) ITO/PEDOT:PSS/ $\mathrm{CuPc}_{0.5}: \mathrm{C} 60_{0.5} / \mathrm{BCP} / \mathrm{Al}(\mathbf{\square})$.

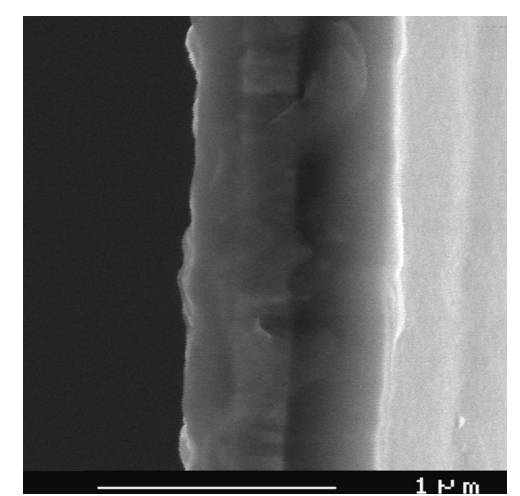

Figure 5: Cross-sectional SEM micrograph of glass/ITO/PEDOT: $\mathrm{PSS} / \mathrm{P} 3 \mathrm{HT}_{0.3}: \mathrm{CuPc}_{0.3}: \mathrm{C} 60_{0.4}$.

$\mathrm{BCP} / \mathrm{Al}$ device develops an open circuit voltage $V_{\mathrm{OC}}$ of $0.63 \mathrm{~V}$, a short circuit current $I_{\mathrm{SC}}$ of $6.5 \mathrm{~mA} / \mathrm{cm}^{2}$, a fill factor of 0.68 , and an energy conversion efficiency $\eta=$ $2.8 \%$. As a result of heat treatment, the organic solar cell performance was dramatically improved. We can conclude that thermal annealing enhances photovoltaic characteristics by optimizing both the morphology and the stability of the photoactive layer.

Finely, cross-sectional SEM micrograph of glass/ITO/ PEDOT:PSS/P3HT $\mathrm{H}_{0.3}: \mathrm{CuPc}_{0.3}: \mathrm{C} 60_{0.4}$ structure was checked by cross-section visualization using a scanning electron microscope (SEM) after one month under both environmental and light exposure (Figure 5). We can see that there are no chemical degradation and phase segregation. We can note that the addition of P3HT stabilizes the photoactive layer by reducing the density of structural defects and phase segregation.

\section{Conclusions}

The addition of P3HT in CuPc:C60 thin films has been studied by $I-V$ measurements under AM 1.5 illumination. The incorporation of $\mathrm{P} 3 \mathrm{HT}$ in the films improved the optical properties of the $\mathrm{CuPc}-\mathrm{C} 60$ thin films and increased the solar cell parameters values $\left(I_{\mathrm{SC}}\right.$ and $\left.\eta\right)$ from 4.93 to $5.7 \mathrm{~mA} / \mathrm{cm}^{2}$ and from 1.02 to $1.44 \%$, respectively. In addition, thermal annealing, for $15 \mathrm{~min}$ at $100^{\circ} \mathrm{C}$, stabilizes the bulk heterojunction photoactive layer making it more robust to chemical degradation under prolonged operation and improves the power conversion efficiency to $2.8 \%$.

\section{References}

[1] I. Murtaza, I. Qazi, and K. S. Karimov, "CuPc/C60 heterojunction thin film optoelectronic devices," Journal of Semiconductors, vol. 31, no. 6, Article ID 064005, 2010.

[2] Y. Chen and D. Ma, "Organic semiconductor heterojunction as charge generation layers and its application in tandem organic light-emitting diodes for high power efficiency," Journal of Materials Chemistry, vol. 98, Article ID 243309, 2012.

[3] J. H. Lee and J. J. Kim, "Interfacial doping for efficient charge injection in organic semiconductors," Physica Status Solidi (A), vol. 209, no. 8, pp. 1399-1413, 2012.

[4] M. Bronner, A. Opitz, and W. Brütting, "Ambipolar charge carrier transport in organic semiconductor blends of phthalocyanine and fullerene," Physica Status Solidi (A) Applications and Materials, vol. 205, no. 3, pp. 549-563, 2008.

[5] J. Endres, U. Hörmann, J. Niederhausen et al., "Correlation between interface energetics and open circuit voltage in organic photovoltaic cells," Applied Physics Letters, vol. 101, no. 23, Article ID 233301, 2012.

[6] B. Li, J. Chen, D. Yang, and D. Ma, "A comparative investigation of trap-limited hole transport properties in organic bulk heterojunctions," Semiconductor Science and Technology, vol. 26, no. 11, Article ID 115006, 2011.

[7] K. Akaike, A. Opitz, J. Wagner et al., "Unoccupied states in copper phthalocyanine/fullerene blended films determined by inverse photoemission spectroscopy," Organic Electronics, vol. 11, no. 11, pp. 1853-1857, 2010.

[8] B. B. Yang, D. D. Zhang, S. T. Lee, Y. Q. Li, and J. X. Tang, "Efficiency enhancement of organic photovoltaic devices using a Sm: Al compound electrode," Applied Physics Letters, vol. 102, no. 7, Article ID 073301, 2013.

[9] H. Kumar, P. Kumar, N. Chaudhary et al., "Effect of temperature on the performance of $\mathrm{CuPc} / \mathrm{C} 60$ photovoltaic device," Journal of Physics D, vol. 42, no. 1, Article ID 015102, 2009.

[10] J. Park, J. E. Royer, C. N. Colesniuc et al., "Ambient induced degradation and chemically activated recovery in copper phthalocyanine thin film transistors," Journal of Applied Physics, vol. 106, no. 3, Article ID 034505, 2009.

[11] M. Guan, G. Cao, X. Chu, Y. Zhang, X. Liu, and Y. Zeng, "Effect of $\mathrm{MoO}_{3}$-doped PTCDA as buffer layer on the performance of CuPc/C60 solar cells," Physica Status Solidi (A), 2013.

[12] C. C. Chou, H. C. Wu, C. J. Lin, E. Ghelichkhani, and W. C. Chen, "Morphology and field-effect transistor characteristics of electrospun nanofibers prepared from crystalline poly (3-hexylthiophene) and polyacrylate blends," Macromolecular Chemistry and Physics, vol. 214, no. 7, pp. 751-760, 2013. 
[13] S. Nam, J. Seo, S. Park et al., "Hybrid phototransistors based on bulk heterojunction films of poly (3-hexylthiophene) and zinc oxide nanoparticle," ACS Applied Materials \& Interfaces, vol. 5, no. 4, pp. 1385-1392, 2013.

[14] L. Li, D. L. Jacobs, Y. Che et al., "Poly(3-hexylthiophene) nanofiber networks for enhancing the morphology stability of polymer solar cells," Organic Electronics, vol. 14, no. 5, pp. 13831390, 2013.

[15] D. C. Coffey, A. J. Ferguson, N. Kopidakis, and G. Rumbles, "Photovoltaic charge generation in organic semiconductors based on long-range energy transfer," ACS Nano, vol. 4, no. 9, pp. 5437-5445, 2010.

[16] H. X. Wei, J. Li, Z. Q. Xu, Y. Cai, J. X. Tang, and Y. Q. Li, “Thermal annealing-induced vertical phase separation of copper phthalocyanine: Fullerene bulk heterojunction in organic photovoltaic cells," Applied Physics Letters, vol. 97, no. 8, Article ID 083302, 2010.

[17] N. N. Wang, J. S. Yu, Z. L. Yuan, and Y. D. Jiang, "Effect of annealing copper phthalocyanine on the performance of interdigitated bulk-heterojunction organic photovoltaic cells," The European Physical Journal Applied Physics, vol. 58, no. 2, Article ID 20201, 2012.

[18] N. D. Treat, C. G. Shuttle, M. F. Toney, C. J. Hawker, and M. L. Chabinyc, "In situ measurement of power conversion efficiency and molecular ordering during thermal annealing in P3HT: PCBM bulk heterojunction solar cells," Journal of Materials Chemistry, vol. 21, no. 39, pp. 15224-15231, 2011.

[19] E. Verploegen, R. Mondal, C. J. Bettinger, S. Sok, M. F. Toney, and Z. Bao, "Effects of thermal annealing upon the morphology of polymer-fullerene blends," Advanced Functional Materials, vol. 20, no. 20, pp. 3519-3529, 2010.

[20] J. Mack and M. J. Stillman, "Transition assignments in the Ultraviolet-Visible absorption and magnetic circular dichroism spectra of phthalocyanines," Inorganic Chemistry, vol. 40, no. 4, pp. 812-814, 2001.

[21] T. A. Chen, X. Wu, and R. D. Rieke, "Regiocontrolled synthesis of poly(3-alkylthiophenes) mediated by Rieke zinc: their characterization and solid-state properties," Journal of the American Chemical Society, vol. 117, no. 1, pp. 233-244, 1995.

[22] M. C. Gurau, D. M. Delongchamp, B. M. Vogel et al., "Measuring molecular order in poly(3-alkylthiophene) thin films with polarizing spectroscopies," Langmuir, vol. 23 , no. 2, pp. 834842, 2007.

[23] M. Theander, O. Inganäs, W. Mammo, T. Olinga, M. Svensson, and M. R. Andersson, "Photophysics of substituted polythiophenes," Journal of Physical Chemistry B, vol. 103, no. 37, pp. 7771-7780, 1999. 

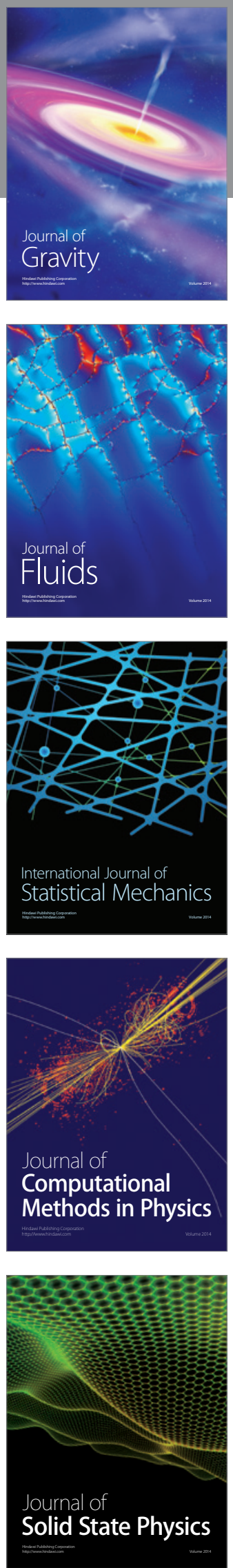

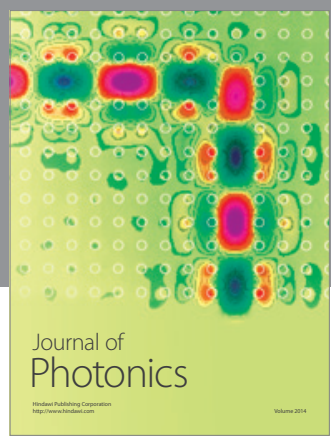

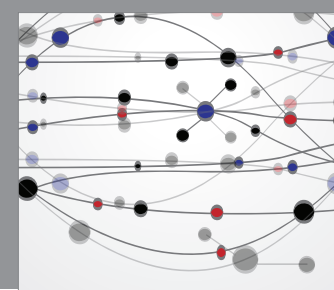

The Scientific World Journal

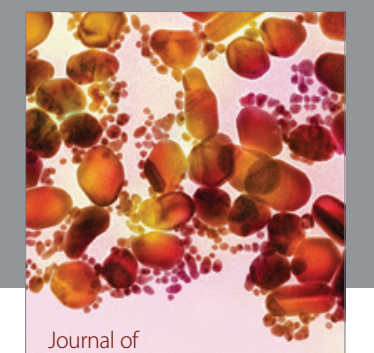

Soft Matter
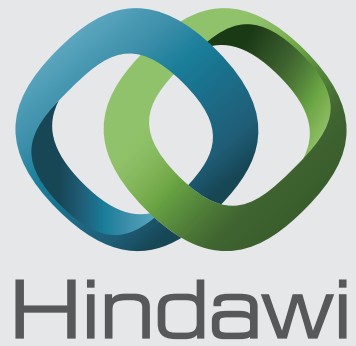

Submit your manuscripts at

http://www.hindawi.com
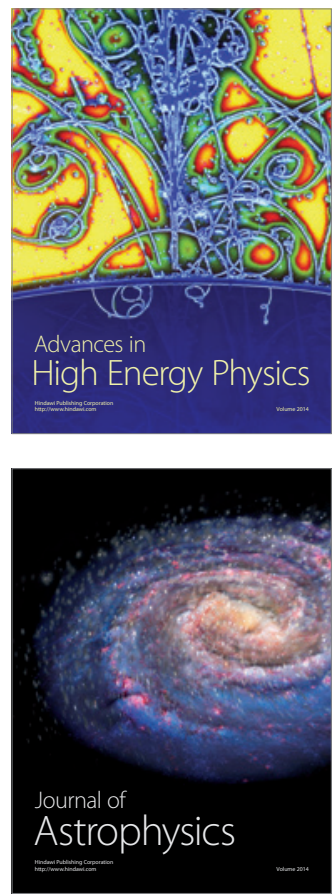
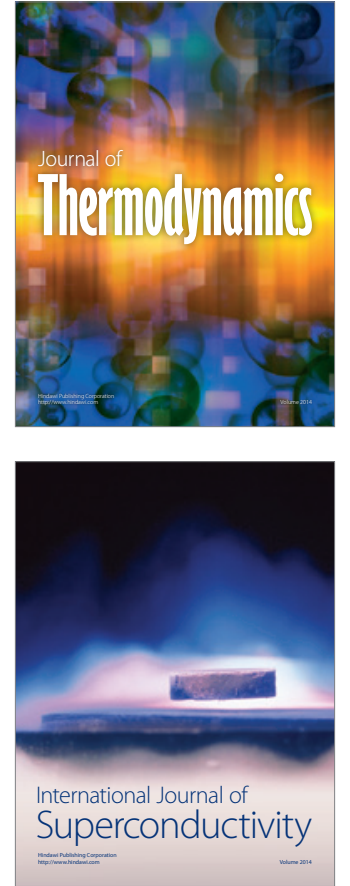
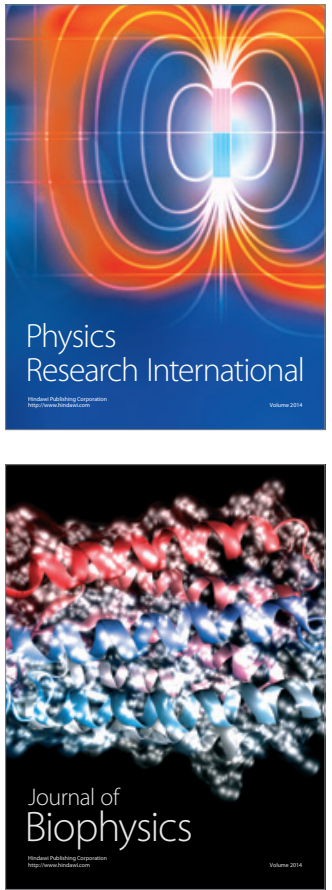
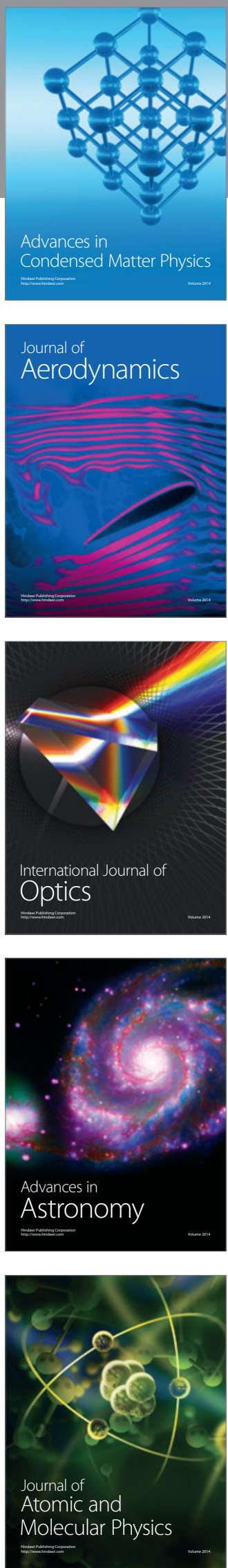